Ann. Zootech., 1980, 29, no h. s., 233-250.

\title{
Effect of energy density of diets for intensive bull beef production on intake, growth rate and feed conversion
}

\author{
Ch. V. BOUCQUE, L.O. FIEMS, R.J. MOERMANS, B.G. COTTYN \\ and F.X. BUYSSE \\ National Institute for Animal Nutrition, \\ Scheldeweg 68, B9231, Melle-Gontrode (Belgium).
}

\begin{abstract}
The impact of the energy concentration ( $\mathrm{kg} \mathrm{SU} / \mathrm{kg} \mathrm{DM}$ ) of ad libitum fed diets, on intake, growth rate and efficiency was investigated with 119 groups loose housed Belgian white-blue store bulls (I), 62 groups of individually tied up Belgian white-blue store bulls (II) and 42 groups of individually tied up Belgian white-red baby-beef bulls (III). We established a negative relationship between the energy density $(x)$ and the dry matter intake $(y=g$ DM/kg Wo. 75).
\end{abstract}

$$
\begin{aligned}
& \text { Group I : } y=136.1-68.7 x ; r=-0.72^{* * ;} ; \mathrm{SD}=5.0 \\
& \text { Group II : } y=139.2-87.6 x ; r=-0.67^{* *} ; \mathrm{SD}=7.0 \\
& \text { Group III : } y=120.6-51.1 x ; r=-0.49^{* *} ; \mathrm{SD}=5.5
\end{aligned}
$$

Within the studied range of energy density $(0.53$ to $0.89 \mathrm{~kg} \mathrm{SU} / \mathrm{kg}$ DM) the relationship with energy intake ( $\mathrm{y}=\mathrm{g} \mathrm{SU} / \mathrm{kg}$ Wo. 75) was positive :

$$
\begin{aligned}
& \text { Group I : } y=33.2+40.0 x ; r=0.67^{* *} ; \mathrm{SD}=3.3 \\
& \text { Group II : } y=41.6+17.9 x ; r=0.28^{*} ; \mathrm{SD}=4.3 \\
& \text { Group III : } y=30.6+41.2 x ; r=0.52^{* *} ; \mathrm{SD}=4.1
\end{aligned}
$$

The increasing energy intake with higher energy densities $(x)$ resulted in an increasing growth rate $(y=\mathrm{g} / \mathrm{d})$ (except for group II) but the correlation was lower :

$$
\begin{aligned}
& \text { Group I : } y=708.1+780.6 x ; r=0.49 * \% \text {;D }=105.8 \\
& \text { Group II }: y=1009.4+119.5 x ; r=0.09 \mathrm{NS} ; \mathrm{SD}=93.8 \\
& \text { Group III }: y=823.5+464.6 x ; r=0.36^{*} ; \mathrm{SD}=71.3
\end{aligned}
$$

The feed conversion ( $y=\mathrm{kg} \mathrm{SU} / \mathrm{kg}$ gain) in function of the energy concentration $(x)$ did not indicate a significant relationship for two of the three groups :

$$
\begin{aligned}
& \text { Group I : } y=4.31+0.61 x ; r=0.12 \mathrm{NS} ; \mathrm{SD}=0.37 \\
& \text { Group II :y=2.84+2.35x;r=0.42**; SD }=0.37 \\
& \text { Group III : } y=3.79+0.22 x ; r=0.06 \mathrm{NS} ; \mathrm{SD}=0.22
\end{aligned}
$$


Ad libitum feeding of higher energetic rations resulted in decreased dry matter and increased net energy intake. Daily liveweight gain was positively affected by a higher energy density, while the influence on the feed conversion was very small, except for the tied store bulls.

\section{Résumé}

\section{Influence de la concentration énergétique des rations sur la consommation, la vitesse de croissance "et l'efficacité alimentaire de jeunes bovins intensifs}

Les auteurs ont étudié les effets de la concentration énergétique (Valeur Amidon/ $\mathrm{kg}$ de MS) de rations offertes à volonté sur la consommation, la vitesse de croissance et l'efficacité alimentaire de 119 lots de taurillons Blanc-Bleu-Belges en stabulation libre (I), 62 lots de taurillons Blanc-Bleu-Belges en stabulation entravée (II) et de 42 groupes de taurillons Blanc-Rouge-Belges en stabulation entravée (III). Ils ont établi une liaison négative entre la concentration énergétique $(x)$ et la quantité de matière sèche ingérée (y $=\mathrm{MS} / \mathrm{kg}$ poidso, 75).

$$
\begin{aligned}
& \text { Lot I : } y=136,1-68,7 x ; r=-0,72^{* *} ; \mathrm{SD}=5,0 \\
& \text { Lot II :y=139,2-87,6x;r=-0,67*; SD }=7,0 \\
& \text { Lot III }: y=120,6-51,1 x ; r=-0,49^{* * ;} \text { SD }=5,5
\end{aligned}
$$

Dans l'intervalle de concentration énergétique considéré $(0,53$ à 0,89 UA/ $\mathrm{kg}$ MS) la liaison avec la quantité d'énergie ingérée $(y=\mathrm{UA} / \mathrm{kg} \mathrm{Po}, 75)$ a été positive.

$$
\begin{aligned}
& \text { Lot I :y=33,2+40,0 } x ; r=0,67^{* *} ; \mathrm{SD}=3,3 \\
& \text { Lot II :y=41,6+17,9 } x ; r=0,28^{*} ; \mathrm{SD}=4,3 \\
& \text { Lot III }: y=30,6+41,2 x ; r=0,52^{* *} ; \mathrm{SD}=4,1
\end{aligned}
$$

L'accroissement de la quantité d'énergie ingérée lié à celui de la concentration énergétique $(x)$ a entraîné une augmentation de la vitesse de croissance $(y=\mathrm{g} /$ jour) (sauf pour le lot II), mais avec de plus faibles corrélations.

$$
\begin{aligned}
& \text { Lot I :y=708,1+780,6x;r=0,49**; SD }=105,8 \\
& \text { Lot II :y=1009,4+119,5x;r=0,09 NS;SD }=93,8 \\
& \text { Lot III }: y=823,5+464,6 x ; r=0,36^{*} ; \text { SD }=71,3
\end{aligned}
$$

La relation entre le coût énergétique $\mathrm{du} \mathrm{kg}$ de gain $(\mathrm{y}=\mathrm{VA} / \mathrm{kg}$ gain) et la concentration énergétique $(x)$ n'a pas été significative pour 2 des 3 lots.

$$
\begin{aligned}
& \text { Lot I :y=4,31+0,61 } x ; r=0,12 \mathrm{NS} ; \mathrm{SD}=0,37 \\
& \text { Lot II :y=2,84+2,35x;r=0,42**; SD }=0,37 \\
& \text { Lot III }: y=3,79+0,22 x ; r=0,06 \mathrm{NS} ; \mathrm{SD}=0,22
\end{aligned}
$$

La distribution à volonté de rations de plus en plus riches en énergie a entrainé une réduction de la quantité de matière sèche ingérée et une augmentation de la quantité d'énergie ingérée ; les gains de poids vif journaliers ont été améliorés par l'accroissement de la concentration énergétique tandis que l'efficacité alimentaire a été peu modifiée, sauf pour les taurillons II en stabulation entravée.

\section{1. - Introduction}

There is a great diversity of beef production in Europe, due in part to the large number of breeds with their own genotype. Bulls of Anglo-Saxon and dairy breeds have an early maturity which results in fatter carcases compared to the continental beef breeds. The variability in the performance of beef cattle can be 
further enhanced when animals receive different feeding levels (GEAY and RoBELIN, 1979). A higher energy level either increased the fat content in the carcase at equal carcase weights, or decreased carcase weight at an equal fat content (Callow, 1961 ; HenricKson et al., 1965 ; Garrigus et al., 1969 ; WaldMan et al., 1971 ; Bond et al., 1972 ; ANDERSEN, 1975). When reared in the same conditions, bulls of different breeds with equal carcase weights gave a different fat content in the carcase or when the fat content was comparable, there was a difference in carcase weight (Geay and Malterre, 1973).

Variability also exists concerning feed conversion data cited in the literature, even within the same category of animals fattened with comparable diets. The starch equivalent intake per $\mathrm{kg}$ of liveweight gain of Israeli-Friesian male cattle was 3.8 to $4.2 \mathrm{~kg}$ (LEVY et al., 1968 and 1970) while similar bulls of the Belgian white-red breed had a better feed conversion : 2.9 to 3.4 (BUYSSE, 1969 ; BuYsse and BouCQue, 1975).

However, there is no agreement concerning the effect of decreasing the level of energy intake on feed efficiency. Some feeding experiments reported a better efficiency on a restricted energy level (DE BoER et al., 1971 ; BOND et al., 1972 ; Levy et al., 1974 ; ANDERSEN, 1975), while other trials (GuENTHER et al., 1965 ; MEYER et al., 1965) gave a better efficiency with ad libitum feeding, or no difference (GEAY et al., 1976; LEvy et al., 1976; RoHR and DAENICKE, 1978).

This study will not investigate the influence of energy levels, but rather the impact of the ration energy concentration on feed intake, growth rate and feed conversion of fattening bulls.

\section{2. - Experimental}

The bulls involved with this investigation can be divided in three groups :

I: store bulls of the Belgian white-blue (BWB) breed, group-housed (119 rations with 929 animals, liveweight range of $292.4 \pm 4.1\left(s_{x}^{-}\right)$to $596.2 \pm 3.1 \mathrm{~kg}$ );

II: store bulls of the BWB breed, but individually tied up (62 rations with 439 animals, liveweight range of $260.0 \pm 3.5$ to $543.9 \pm 4.1 \mathrm{~kg}$ );

III: baby-beef bulls of the Belgian white-red (BWR) breed, individually tied up (42 rations with 265 animals, liveweight range of $159.2 \pm 4.2$ to $479.9 \pm 2.5 \mathrm{~kg}$ ).

In each group there was a diversity of diets varying from complete dry rations to mixed rations. For the mixed diets the basic feedstuff was always administered to appetite, while the daily allowance of concentrate was restricted to 1 or $0.75 \mathrm{~kg}$ per $100 \mathrm{~kg}$ liveweight. Therefore the animals were weighed monthly and the amount of concentrate was adapted accordingly. Initial and final weights were recorded on three and two consecutive days respectively. The main roughages were maize silage, dehydrated alfalfa pellets, dehydrated whole maize plant pellets, grass hay and also some industrial by-products (BOUCQUE et al., 1978) (Table 1).

All rations were chemically analysed and digestibility of the complete diets or of the main feedstuffs was determined with wethers as described by CoTTYN and BouCQUe (1969). 
TABLE 1

CLASSIFICATION OF THE RATIONS FOLLOWING THE BASIC FEEDSTUFFS AND THE ENERGY DENSITY

\begin{tabular}{|c|c|c|c|}
\hline Ration type & $(\mathrm{n}=119)$ & $\begin{array}{c}\text { II } \\
(\mathrm{n}=62)\end{array}$ & $\begin{array}{c}\text { III } \\
(n=42)\end{array}$ \\
\hline Hay + concentrate & - & 14 & - \\
\hline Maize silage + concentrate & 18 & 24 & - \\
\hline $\begin{array}{l}\text { Dehydrated maize pellets }+ \\
\text { concentrate }\end{array}$ & 6 & 4 & 8 \\
\hline $\begin{array}{l}\text { Dehydrated alfalfa pellets }+ \\
\text { concentrate }\end{array}$ & 20 & - & - \\
\hline Fodderbeet + concentrate & 1 & - & - \\
\hline $\begin{array}{l}\text { Ensiled pressed beet pulp }+ \\
\text { concentrate }\end{array}$ & 7 & - & - \\
\hline $\begin{array}{l}\text { Dried beet pulp }(\geqslant 758) \\
\text { rations }\end{array}$ & 14 & 6 & - \\
\hline Complete dry rations ${ }^{*}$ & 49 & 12 & 28 \\
\hline Maize grain + concentrate & 4 & 2 & 6 \\
\hline $\begin{array}{l}\text { Energy density of the diet } \\
(\mathrm{kg} \mathrm{sU} / \mathrm{kg} \text { DM })\end{array}$ & & & \\
\hline$<0.600$ & 12 & 12 & - \\
\hline $0.600-0.649$ & 10 & 5 & 3 \\
\hline $0.650-0.699$ & 30 & $\underline{21}$ & 3 \\
\hline $0.700-0.749$ & 33 & 19 & 23 \\
\hline $0.750-0.799$ & 20 & 3 & 7 \\
\hline $0.800-0.849$ & 11 & - & 3 \\
\hline$\geqslant 0.850$ & 3 & 2 & 3 \\
\hline
\end{tabular}

* Mainly aried sugar beet pulp and other by-products

The impact of the energy concentration on dry matter and net energy intake, growth rate and feed conversion was studied by regression analysis (DRAPER and SMITH, 1966).

The net energy content was expressed in starch equivalents. The requirements for maintenance and daily liveweight gain (LWG) were calculated by the following regressions (BUYSSE, 1974) :

SE for maintenance $(\mathrm{kg} / \mathrm{d})=0.8+0.0045 \mathrm{~W}$

$\mathrm{SE}$ for production $(\mathrm{kg} / \mathrm{kg} \mathrm{LWG})=1.22+0.00273 \mathrm{~W}$. 


\section{3. - Results and discussion}

\section{1. - Feed intake}

According to the studies of Montgommery and Baumgardt (1965) ; Baumgard (1970) and Dinius and BaumGard (1970), we can expect an increasing dry matter and energy intake by enhancing the energy concentration. Once a threshold density is exceeded, there would be no point in a higher energy concentration, because animals eat for calories !

Giving more concentrated rations results in a decreasing dry matter intake and a stable or slightly decreasing energy intake. CONRAD (1966) found that the digestible dry matter intake of dairy cows levelled off and approached a straight line between 66 and 80 per cent DM digestibility. The DM digestibility of the diets concerned in this study ranged between 66 and 87 per cent.

Our investigation always resulted in a decreasing DM intake $\left(y=\mathrm{g} / \mathrm{kg} \mathrm{W}^{\mathbf{0 . 7 5}}\right)$ (figure 1) with increasing energy concentration $(x=\mathrm{kg} \mathrm{SU} / \mathrm{kg} \mathrm{DM})$.

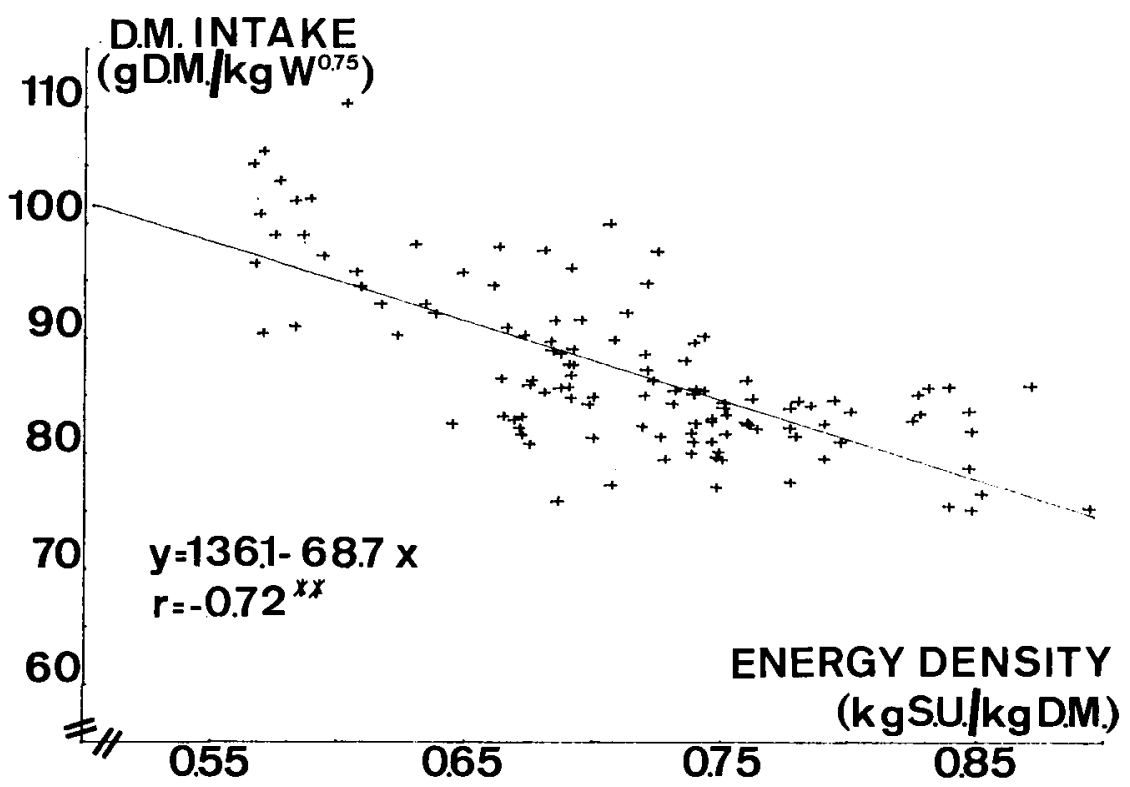

FIG 1. - Relationship, energy density and DM intake by bulls (I).

The relationship was respectively :

$$
\begin{aligned}
& \text { Group I : } y=136.1-68.7 x ; r=-0.72^{* *} ; \mathrm{SD}=5.0 \\
& \text { Group II }: y=139.2-87.6 x ; r=-0.67^{* *} ; \mathrm{SD}=7.0 \\
& \text { Group III : } y=120.6-51.1 x ; r=-0.49^{* *} ; \mathrm{SD}=5.5
\end{aligned}
$$

These findings are in accordance with most of the literature data shown in 


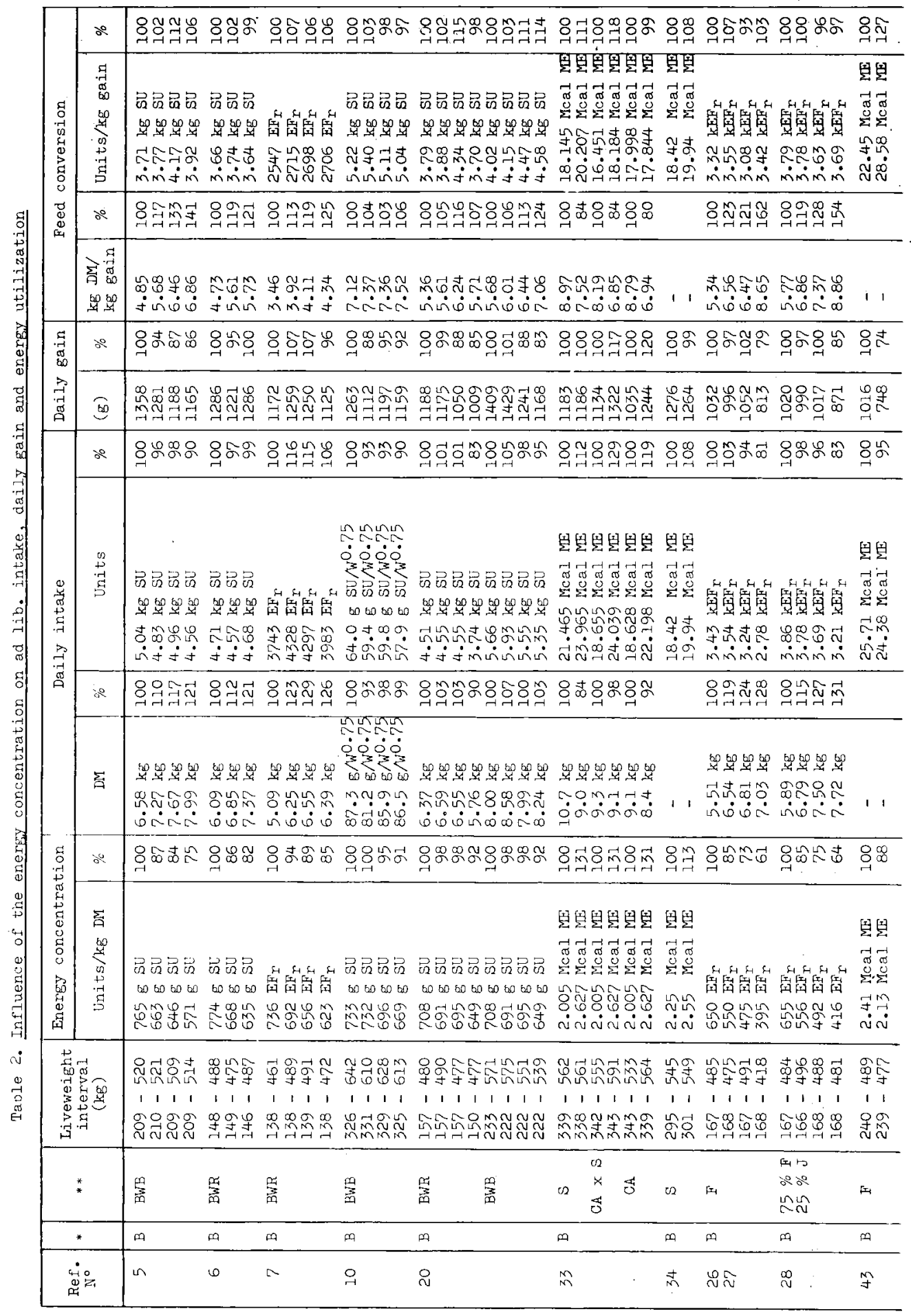




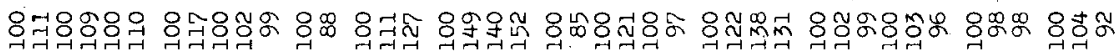

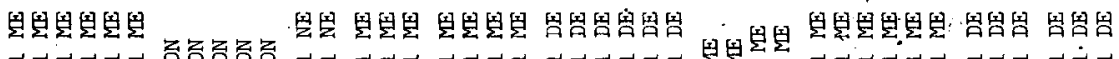

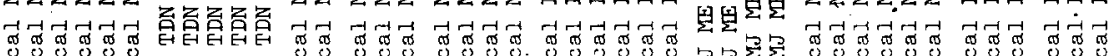

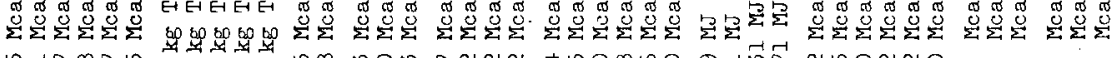

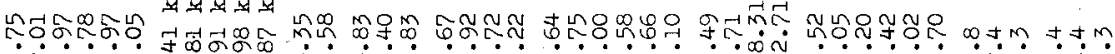
๙ஷ்

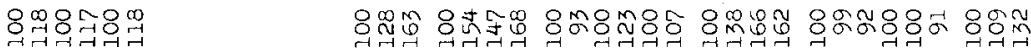

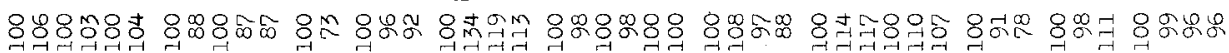

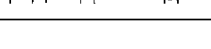

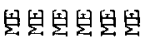

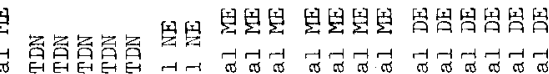

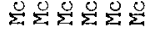

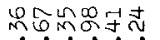

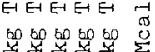

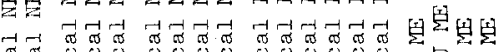

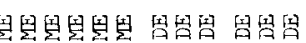

$\ln \sin 2 \pi$

₹ं宀

(.

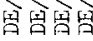

จู่

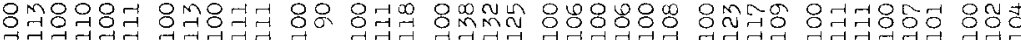

$8 \infty_{-1}^{\infty} \underset{2}{\omega}$

$\therefore$

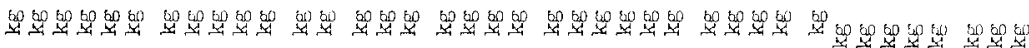

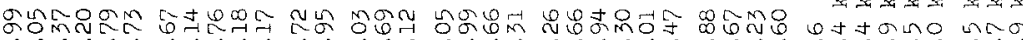

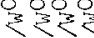

600 tat

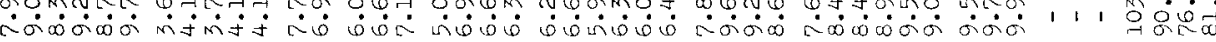

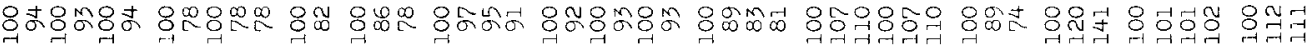

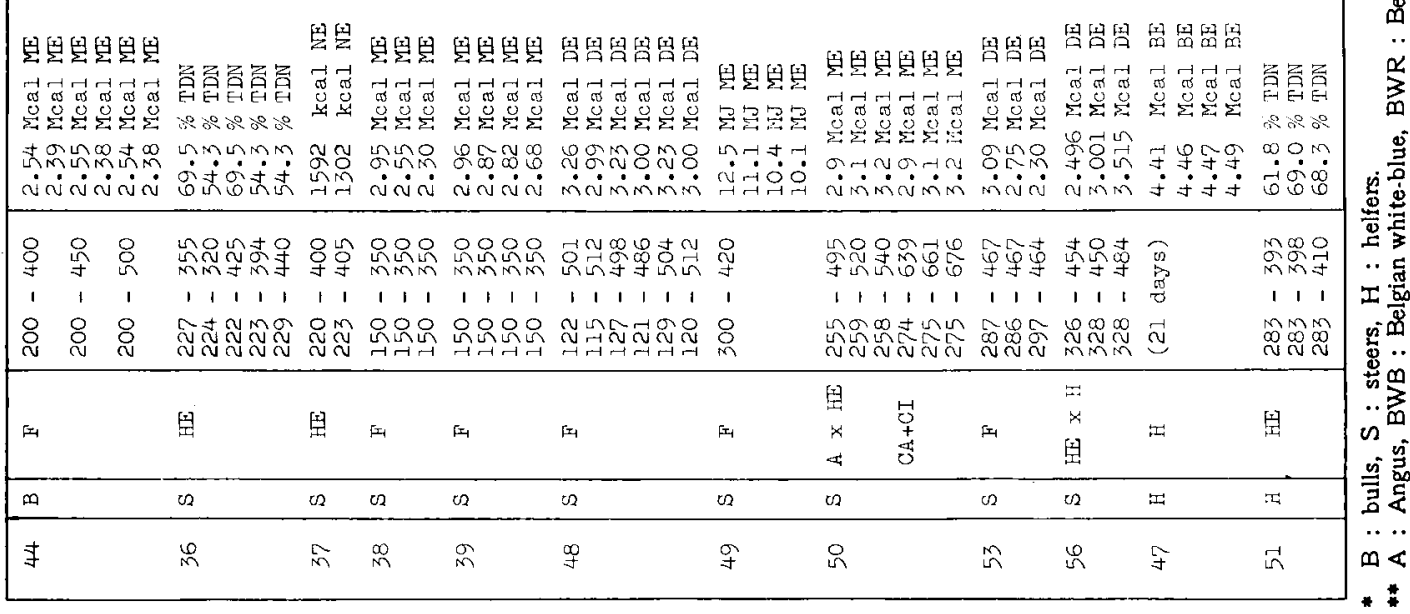


A possible explanation for the diminishing DM intake may be the fact that we had already exceeded the threshold concentration for maximum DM intake.

In that case, the relationship of MONTGOMMERY and BAUMGARDT (1965) suggests a constant energy intake. Nevertheless, in our trials (figure 2) we observed a significantly higher energy intake $\left(y=\mathrm{g} \mathrm{SU} / \mathrm{kg} \mathrm{W}^{0.75}\right)$ with increasing energy density $(x)$ :

$$
\begin{aligned}
& \text { Group I : } y=33.2+40.0 x ; r=0.67^{* *} ; \quad \mathrm{SD}=3.3 \\
& \text { Group III : } y=41.6+17.9 x ; r=0.28^{*} ; \quad \mathrm{SD}=4.3 \\
& \text { Group III : } y=30.6+41.2 x ; \quad r=0.52^{* *} ; \quad \mathrm{SD}=4.1
\end{aligned}
$$

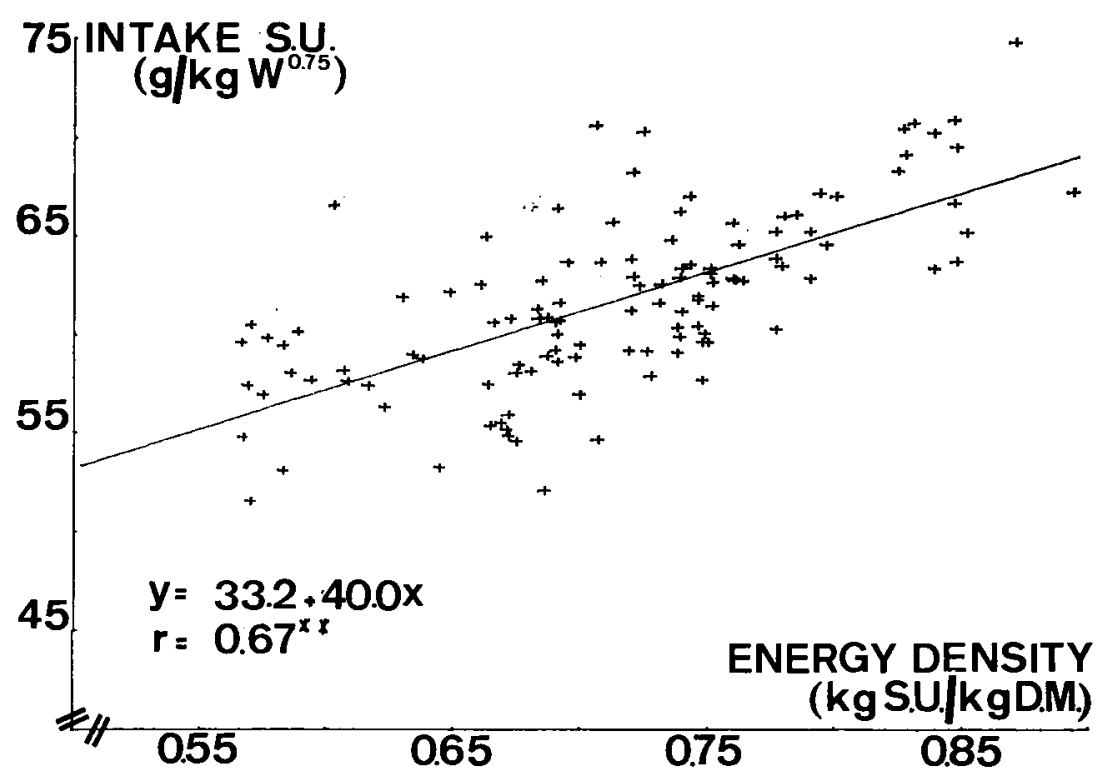

FIG. 2. - Relationship, energy density and SU intake by bulls (BWB-group housed; $n=119)(I)$.

This again is in agreement with most of the cited references in Table 2. However the uniformity among the 3 groups for the energy intake as a consequence of the caloric density is less pronounced than for the DM intake. Feed intake is also influenced by other parameters of the diet such as physical form (CotTyn et al., 1971) and crude fibre content (DE BRABANDER et al., 1978).

FreEr and CAMPLing (1963) noted a lower energy intake on very high energy rations. At our institute CoTTYN et al. (1978) established the same phenomenon with tieds bulls of the Belgian white-blue breed fed maize grain, while it was not confirmed with loose housed bulls (BoucQue et al., 1978). This statement helps to explain the lower $r$ value for group II.

\section{2. - Daily liveweight gain}

Because of the positive correlation between the energy concentration and the energy intake, we expect a higher growth rate $(y=\mathrm{g} /$ day) with increasing energy concentration. This was confirmed by our investigation (Figure 3), but the 
correlation coefficients were lower (especially for group II) than those for intake and concentration. The relationship was respectively :

$$
\begin{aligned}
& \text { Group I }: y=708.1+780.6 x ; r=0.49^{* *} ; \mathrm{SD}=105.8 \\
& \text { Group II }: y=1009.4+119.4 x ; r=0.09 \mathrm{NS} ; \mathrm{SD}=93.8 \\
& \text { Group III }: y=823.5+464.6 x ; r=0.36^{*} ; \mathrm{SD}=71.3
\end{aligned}
$$

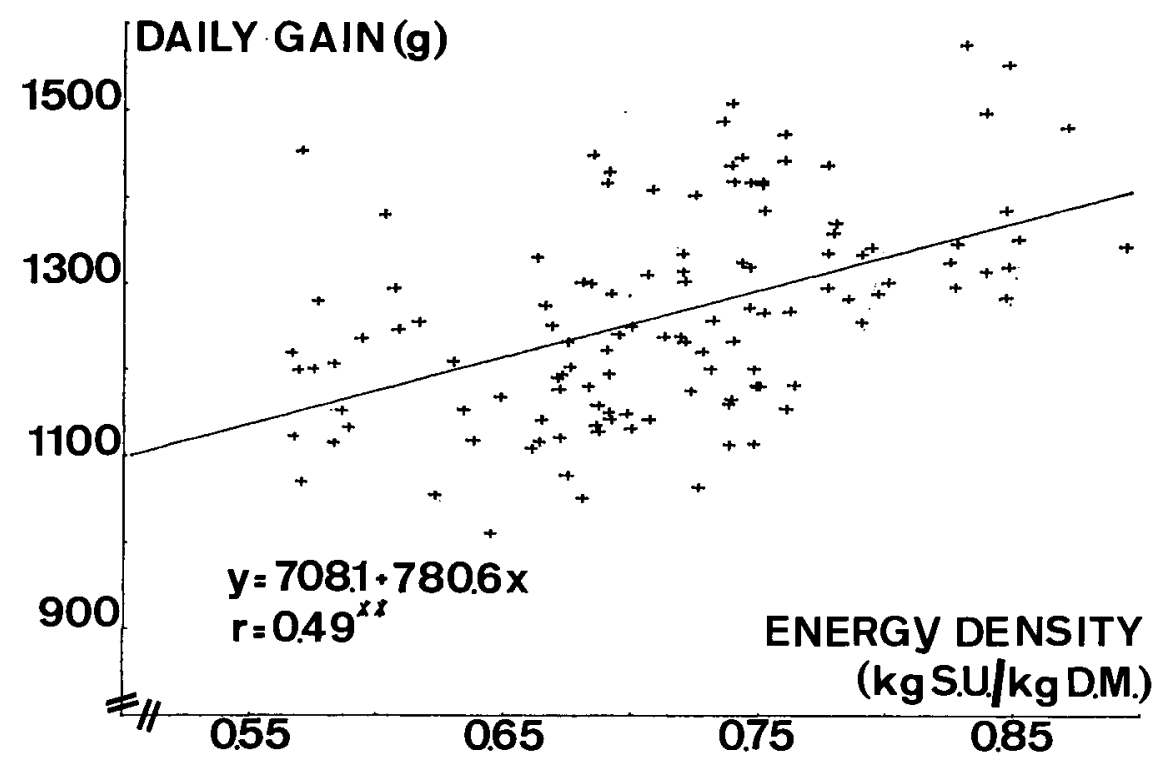

FIG. 3. -- Relationship, energy density and daily gain by bulls (I).

This is also in accordance with the data in Table 2, although some investigations (FLACHOWSKY and LöHNERT, 1977 and FlACHOWSKY, 1979), with high energetic rations but with a lack of fibrous material, resulted in a growth depression without a decreasing energy intake.

LANARI and SUSMEL (1979) found that maize rations with increasing energy concentration clearly improved daily gains of beef breed bulls $(r=0.80)$, while the increase in daily gain was less evident for dairy breed bulls $(r=0.42)$, light steers $(r=0.26)$ and heavy steers $(r=0.67)$.

In the case of store bulls only, there is a clearly better response on energy concentration with loose housed bulls (I) than with tied animals (II). This was already demonstrated with earlier results (BouCQue et al., 1979).

The influence of the daily energy intake $\left(x=\mathrm{g} \mathrm{SU} / \mathrm{kg} \mathrm{W}^{0.75}\right)$ on the daily gain $(y)$ (figure 4 ) gives a more significant relationship:

$$
\begin{aligned}
& \text { Group I : } y=87.1+19.1 x ; \quad r=0.71^{* *} ; \quad \mathrm{SD}=85,8 \\
& \text { Group II }: y=452.4+11.9 x ; \quad r=0.57^{*} ; \quad \mathrm{SD}=77.4 \\
& \text { Group III }: y=462.8+11.5 x ; \quad r=0.72^{* *} ; \quad \mathrm{SD}=53.3
\end{aligned}
$$




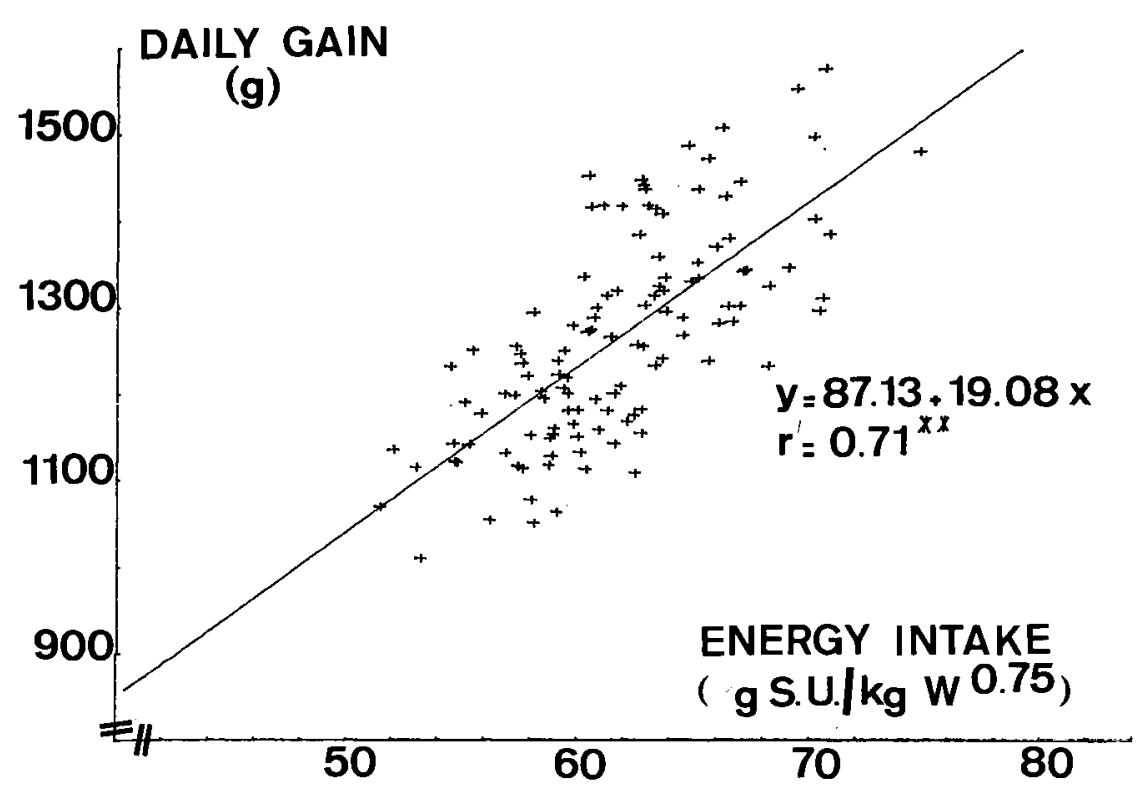

FIG. 4. - Relationship, energy intake and daily gain by bulls (I).

\section{3 - Feed Conversion}

\subsection{Ad libitum energy intake}

Firstly the total energy intake (for maintenance and growth together) per $\mathrm{kg}$ liveweight gain $(\mathrm{y}=\mathrm{kg} \mathrm{SU} / \mathrm{kg}$ gain) was expressed in function of the energy concentration $(x=g \mathrm{SU} / \mathrm{kg} \mathrm{DM})$ (Figure 5). This relationship for the three groups was respectively :

$$
\begin{aligned}
& \text { Group I : } y=4.31+0.61 x ; r=0.12 \mathrm{NS} ; \quad \mathrm{SD}=0.37 \\
& \text { Group II }: y=2.84+2.35 x ; r=0.42^{* *} ; \quad \mathrm{SD}=0.37 \\
& \text { Group III }: y=3.79+0.22 x ; r=0.06 \mathrm{NS} ; \quad \mathrm{SD}=0.22
\end{aligned}
$$

The higher correlation of group II seems a logical consequence of the low correlation between gain and energy density. Because of the positive correlation between energy concentration and energy intake ( $r=0.67,0.28$ and 0.52$)$, we could expect a luxury consumption at higher densities resulting in an unfavourable conversion due to a higher fat deposition. The regression equation for I and III do not sustain this hypothesis. Comparing these results with the data in Table 2, it becomes clear that there is no uniformity in the literature.

Rations with a decreasing energy density often result in a more unfavourable energy conversion (KAY et al., 1970 and 1971 ; BouCQue et al., 1971a and 1972 ; Cottyn et al., 1973 ; Levy et al., 1974 and 1975 ; Pirie and GreenHALGH, 1978) while there are trials with opposite results (HENRICKSON et al., 1965 ; GEAY et al., 1976a, $b$; BouCQUE, 1979) when the range of energy concentration was quite similar. Some authors established no clear effect (GUENTHER et al., 1965 ; Swan and Lamming, 1970 ; BoucQue et al., 1971b ; Prior et al., 


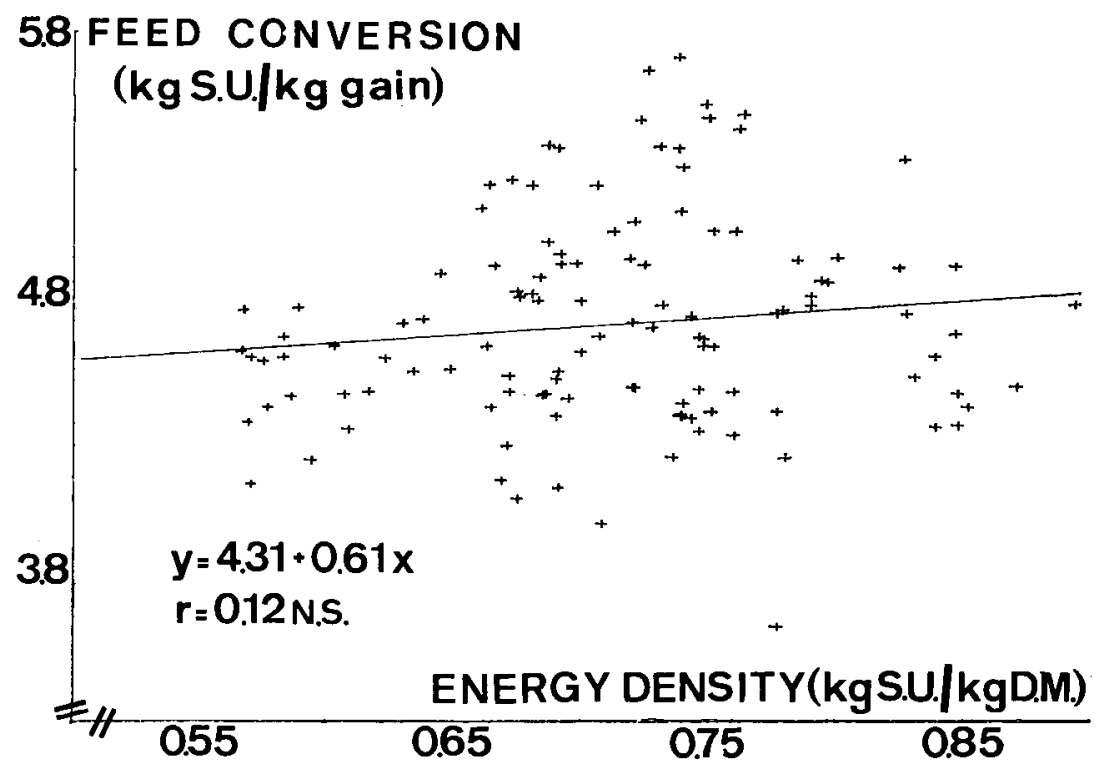

FIG. 5. - Relationship energy density and energy utilzation (I),

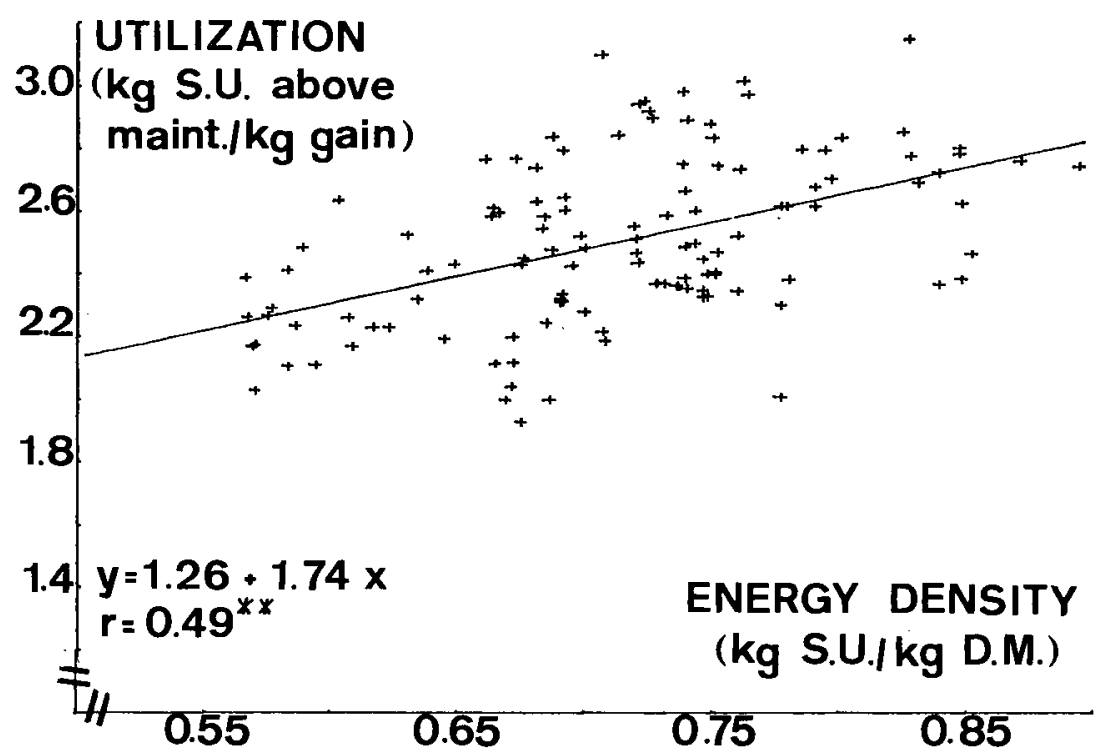

FIG. 6. - Relationship energy density and energy utilization (I).

1977). Certainly there exists a genotype-nutrition interaction (GEAY and RoBELIN, 1979). Rations with increasing energy density resulted in an unfavourable feed conversion of Salers bulls, while there was no influence on feed conversion of Charolais bulls (GEAY et al., 1976a). 
LANARI and SUSmel (1979) concluded that there was no modification in efficiency due to energy concentration with beef breed bulls $(r=0.10)$, but the efficiency declined clearly with dairy breed bulls $(r=0.44)$, light steers $(r=0.71)$ and heavy steers $(r=0.68)$. When we took the liveweight $\left(x_{3}=\mathrm{kg} \mathrm{LW}\right)$ into account (beside the energy density $x_{1}$ ), we obtained the following multiple linear regression :

$$
\begin{aligned}
& \text { Group I : } y=1.75+0.27 x_{1}+0.0063 x_{2} ; \mathrm{R}^{2}=0.31 ; \mathrm{SD}=0.31 \\
& \text { Group II }: y=1.06+1.41 x_{1}+0.0060 x_{2} ; \mathrm{R}^{2}=0.31 ; \mathrm{SD}=0.34 \\
& \text { Group III }: y=1.83+0.69 x_{1}+0.0050 x_{2} ; \mathrm{R}^{2}=0.19 ; \mathrm{SD}=0.20
\end{aligned}
$$

The partial regression coefficients between liveweight $\left(x_{2}\right)$ and energy conversion $(y)$ are $0.56,0.40$ and 0.45 respectively.

Assuming that the maintenance requirements are constant, the energy intake above maintenance per $\mathrm{kg}$ liveweight gain $(y=\mathrm{kg} \mathrm{SU} / \mathrm{kg}$ gain) follows a more uniform pattern compared to the total energy consumption per $\mathrm{kg}$ gain (Figure 6 vs 5 ). In that case, there is a closer relationship with the energy concentration $(x)$.

$$
\begin{array}{ll}
\text { Group I }: y=1.26+1.74 x ; r=0.49 * * ; & \text { SD }=0.23 \\
\text { Group II }: y=0.73+1.90 x ; r=0.44^{* *} ; & \text { SD }=0.28 \\
\text { Group III }: y=1.02+1.36 x ; r=0.36^{*} ; & \text { SD }=0.21
\end{array}
$$

Taking the average liveweight $\left(x_{2}\right)$ into account, the following multiple linear regressions were calculated :

$$
\begin{aligned}
& \text { Group I : } y=0.07+1.58 x_{1}+0.00292 x_{2} ; \mathrm{R}^{2}=0.37 ; \mathrm{SD}=0.23 \\
& \text { Group II }: y=0.71+1.89 x_{1}+0.00006 x_{2} ; \mathrm{R}^{2}=0.19 ; \mathrm{SD}=0.28 \\
& \text { Group III }: y=-0.10+1.63 x_{1}+0.00289 x_{2} ; \mathrm{R}^{2}=0.19 ; \mathrm{SD}=0.21
\end{aligned}
$$

The multiple regressions did not improve the relationship to any considerable extent. The relationship between the total energy intake (for maintenance and growth together) per $\mathrm{kg}$ liveweight gain $(y)$ and the daily gain $(x)$ demonstrates the beneficial effect of rapid growing animals :

$$
\begin{aligned}
& \text { Group I }: y=6.55-0.00143 x ; r=-0.46^{* *} ; \quad \mathrm{SD}=0.34 \\
& \text { Group II : } y=6.81-0.00218 x ; r=-0.51^{* *} ; \mathrm{SD}=0.35 \\
& \text { Group III }: y=4.14-0.00016 x ; r=-0.05 \mathrm{NS} ; \mathrm{SD}=0.22
\end{aligned}
$$

The low $r$ value for group III can be explained by the smaller range of liveweight gain (1009 to $1333 \mathrm{~g})$ compared to group I (1010 to $1576 \mathrm{~g})$ and II (899 to $1397 \mathrm{~g}$ ). Considering the energy intake above maintenance per $\mathrm{kg}$ liveweight gain $(y)$ in function of the growth rate $(x)$, the increase of energy consumed per unit of liveweight gain is generally rather low (except for group III) :

$$
\begin{array}{ll}
\text { Group I }: y=2.27+0.00018 x ; r=0.08 \mathrm{NS} ; & \mathrm{SD}=0.27 \\
\text { Group II }: y=1.90+0.00012 x ; r=0.03 \mathrm{NS} ; & \mathrm{SD}=0.31 \\
\text { Group III }: y=0.44+0.00136 x ; r=0.46^{* *} ; & \mathrm{SD}=0.20
\end{array}
$$

\subsection{Different energy levels}

When a particular ration is fed at different levels one could expect the same result as when giving rations with different energy concentration to appetite. However, energy utilisation is more dependent on levels than on concentrations. The data in Table 3 mostly indicate a more favourable feed conversion at 80 


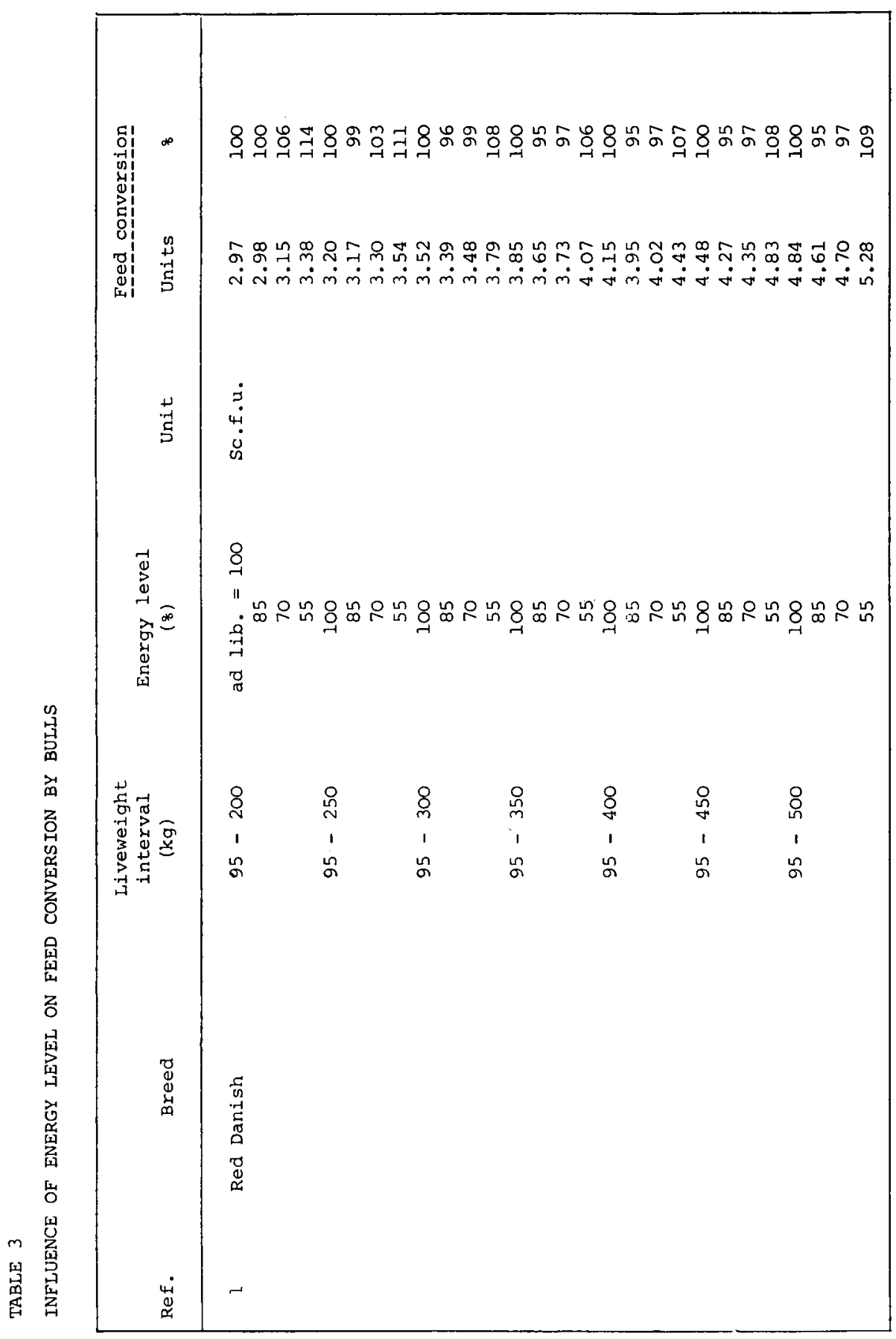




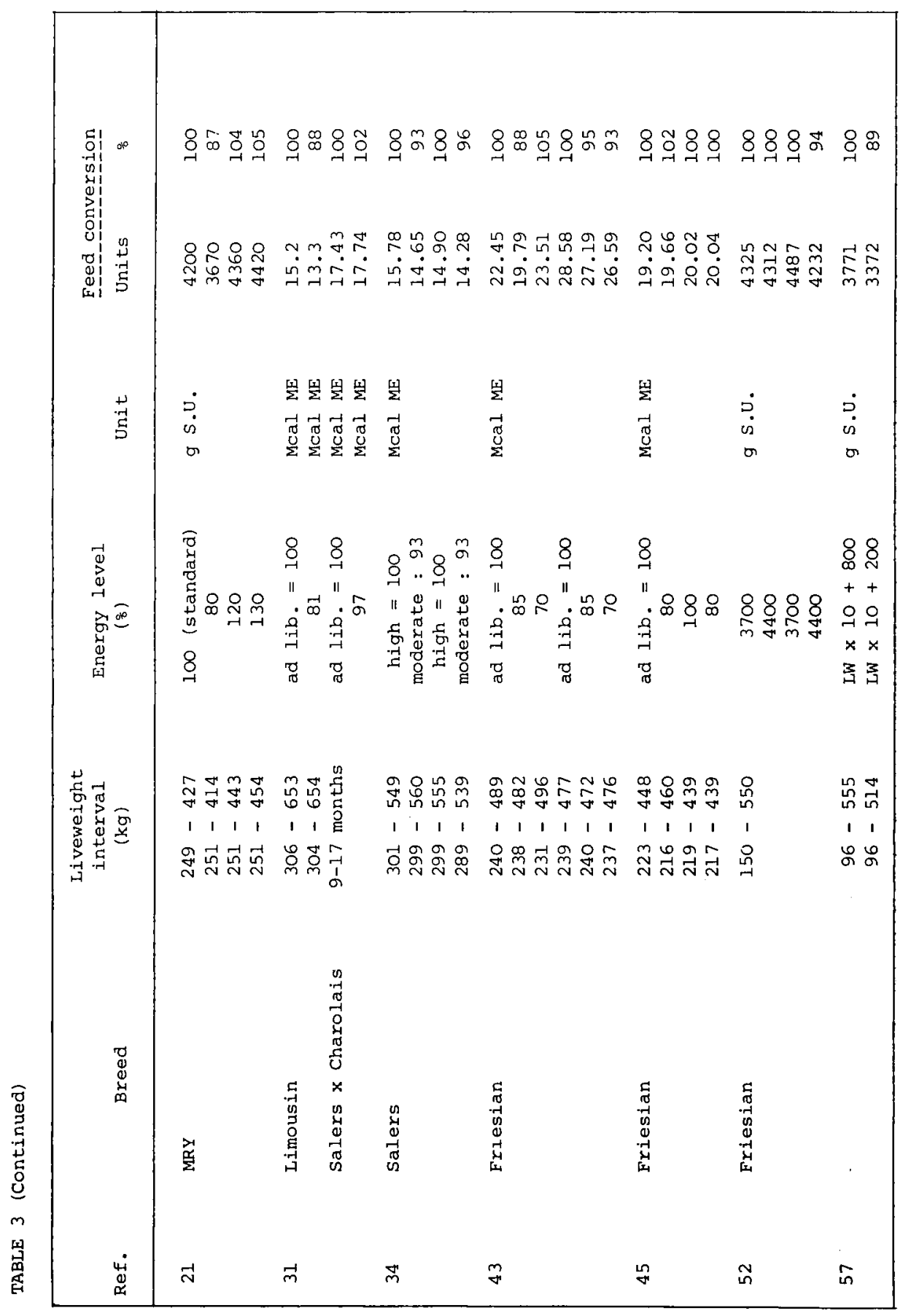


to 85 per cent of the ad libitum intake. Some investigations assume an interaction between energy level and energy concentration in the ration (LEVY et al., 1974 ; ROHR and DAENICKE, 1978). Severe restriction (ANDERSEN, 1975) resulted in a pronounced unfavorable feed conversion. These statements can be explained by a less efficient energy utilisation at high energy levels due to a higher fat deposition (BERGEN, 1974) and higher energy requirements (VAN Es, 1976) on the one side, and to a relatively higher maintenance requirement at low densities on the other hand. Elsley (1976) also established this phenomenon for pigs. The genotype-nutrition-interaction was demonstrated by GEAY and RoBELIN (1979).

\section{4. - Conclusion}

Diets with increasing energy densities, fed ad libtum to intensively fattened bulls of Belgian dual purpose breeds generally resulted in a decreased daily dry matter and an increased energy intake. The positive effect on growth rate was only significant for the loose housed store bulls and the tied baby-beef bulls. For these two groups the energy density of the diet did not modify the feed conversion to any considerable extent. For the tied store bulls however, higher energy diets resulted in a less favourable feed conversion due to a negligible growth response to increased energy intake.

When different energy levels are applied, generally lower growth rates were obtained which in many cases resulted in a better feed efficiency. Following many literature data, the most favourable feed conversion was obtained when bulls were fed at 80 to 85 per cent of ad libitum intake.

Besides the study of parameters related to energy content of the diet, our investigation emphasized the beneficial effect of high growth rates on feed conversion.

\section{Acknowledgment}

The technical assistance of the personnel of the Biometric Unit of the Center for Agricultural Research at Merelbeke is gratefully acknowledged. The authors are grateful to Mr. A. Opstal and Mrs. C DE Praeter for skilled technical assistance.

\section{References}

ANDERSEN H.R., 1975. The influence of slaughter weight and level of feeding on growth rate, feed conversion and carcass composition of bulls. Livest. Prod. Sci., 2, 341-356.

BAumgardT B.R., 1970. Control of feed intake in the regulation of energy balance In : Physiology of digestion and metabolism in the ruminant. Ed. A.T. PHILlipson. Oriel Press, Newcastle upon Tyne. 235-253.

Bergen W.G., 1974. Protein synthesis in animal models. J. Anim. Sci., 38, 1079-1091.

Bond J., Hooven Jr, N.W., Warick E.J., Hiner R.L., Richardson G.V., 1972. Influence of breed and plane of nutrition on performance of dairy, dual-purpose and beef steers. II. From 180 days of age to slaughter. J. Anim. Sci., 34, 1046-1053.

Boucque Ch.V., COTTYN B.G., BuYsSE F.X., 1971a. Effects of varying haypellets barley rations on performance of beef cattle. Atti del VI Simposio Internazionale di Zootecnia, Milano 15-17 Aprile, p. 361-376. 
Boucque Ch.V., Cottyn B.G., Buysse F.X., 1971b. Maïs déshydraté et orge aplatie dans les rations complètes pour taurillons à l'engrais. Revue Agric., Brux. 24, 1295-1305.

Bouóque Ch.V., CotTYN B.G., BuYsse F.X., 1972. Valeur comparée d'agglomérés de maïs pâteux déshydraté et de farine de maîs dans des rations sèches complètes pour taurillons à l'engrais. Revue Agric., Brux. 25, 1273-1292.

Boucque Ch.V., CotTYN B.G., Buysse F.X., 1978. Bull fattening with dehydrated wholecorn-plant pellets compared with corn silage and high-moisture corn grain. Proc. 2nd Intern. Green Crop Drying Congr. University of Saskatchewan, Saskatoon, Canada. 20 25 August, p. 327-33.

Boucque Ch.V., Fiems L.O., CotTyn B.G., Buysse F.X., 1978. Utilisation of some industrial by-products in beef production. Proc. European Congress for Improved Beef Productivity Paris, 28-29 September 1978, Eli Lilly, Saint Cloud, France.

BoucQue Ch.V., 1979. Unpublished data.

Boucque Ch.V., Fiems L.O., CotTyn B.G., Buysse F.X., 1979. The effect of straw bedded loose houses or tie stalls on the performance of finishing bulls. Livest. Prod. Sci., 4, 369-378.

BuYsse F.X., 1969. Intensive beef production. Proc. 8th Intern. Congr. Nutrition. Prague, August 28th - September 5th, 1969. Ed. by Excerpta Medica, Amsterdam, 1970, p. 747-749.

BUYSSE F.X., 1974. Nieuwe inzichten omtrent de energetische voederevaluatie en daarmede aansluitende voerdernormen. Communication of the Institute nr. 304.

BuYsSE F.X., BoucQUe Ch.V., 1975. Present and future beef production systems in Belgium. In : Improving the Nutritional Efficiency of Beef Production. Com, Eur. Com. $5488^{\mathrm{e}}$ Theix 14-17 October, 1975. Ed. by J.C. TAYLER and J.M. Wilkinson, UK, p. 15-35.

Callow E.H., 1961. Comparative studies of meat. VII. A comparison between Hereford, Dairy Shorthorn and Friesian steers on four levels of nutrition. J. Agric. Sci., 56, 265-282.

CONRAD H.R., 1966. Symposium on factors influencing the voluntary intake of herbage by ruminants : physiological and physical factors limiting feed intake. J. Anim. Sci., 25, 227-234.

CotTyn B.G., Boucque Ch.V., 1969. Digestibilité et valeur alimentaire de pulpes séchées de betteraves sucrières. Revue Agric., Brux. 22, 1101-1109.

CotTyn B.G., Boucque Ch.V., Aerts J.V., Buysse F.X., 1978. L'utilisation de maïs-grain humide ou sec dans des rations destinées à la production intensive de viande bovine. Revue Agric., Brux. 31, 295-306.

CotTyn B.G., Boucque Ch.V., Buysse F.X., 1971. Influence de la mouture, de la finesse de mouture et de la mise en agglomérés de foin de prairie sur la production de viande bovine. Revue Agric., Brux. 24, 975-991.

CotTyn B.G., Boucque Ch.V., Buysse F.X., 1973. Possibilités d'utilisation de fanes et cosses de pois déshydratées et agglomérées pour la production de viande bovine. Revue Agric., Brux. 26, 813-827.

De Boer F., Smits B., Dijkstra K.T.J., 1971. Voederhoeveelheid, groei en slachtkwaliteit bij jonge vleesstieren. Landbouwk. Tijdschr. 83, 354-359.

De Brabander D.L., Aerts J.V., Bouqque Ch.V., Buysse F.X., 1978. Intake of preserved grassland products by dairy cattle. Proc. 7 th General Meeting Europ. Grassld Fed. Constraints to Grass Growth and Grassland Output. Ed. by Government Agric. Res. Centre Gent, Merelbeke, Belgium, p. 6.87-6.94.

Dinius D.A., BaumgardT B.R., 1970. Regulation of food intake in Ruminants. 6. Influence of caloric density of pelleted rations. J. Dairy Sci., 53, 311-316.

Draper N.R., SMITH H., 1966. Applied regression analysis. Ed. J. Wiley, New York. 407 pp.

ElsLEy F.W.H., 1976. Limitations to the manipulation of growth. Proc. Nutr. Soc. 35, 325-337.

Flachowsky G., LöHNerT, H.J., 1977. Pelletierte Fertigfuttermittel mit unterschiedlichen Strohanteilen in der Rindermast. 2. Futteraufname und Lebendmasseentwicklung. Tierernährung und Futterung - Erfährungen, Ergebnisse, Entwicklungen. 10, 81-87.

Flachowsky G., Löhnert H.J., Hennig A., 1977. Pelletierte Fertigfuttermittel mit unterschiedlichen Strohanteilen in der Rindermast. 1. Versuchsanstellung und Pansenphysiologische Kennwerte. Tierernährung und Futterung - Erfährungen, Ergebnisse, Entwicklungen 10, 73-80. 
Flachowsky G., 1979. Untersuchungen zum Einfluss einer unterschiedlichen Energiekonzentration in Rationen von Mastrindern verschiendener Genotypen auf Slachtkörperzusammensetzung und Ansatzkriterien. 1. Protein-, Fett- und Energiegehalt in Slachtkörper. Arch. Tierernähr. 29, 17-26.

Freer M., Campling R.C., 1963. Factors affecting the voluntary intake of food by cows. 5. The relationship between the voluntary intake of food, the amount of digesta in the reticulo-rumen and the rate of disappearance of digesta from the alimentary tract with diets of hay, dried grass and concentrates. Br. J. Nutr. 17, 79-88.

Garrigus R.R., Johnson H.R., Thomas N.W., Firth N.L., Harrington R.B., Judge M.D., 1969. Dietary effects on beef composition. I. Quantitative and qualitative carcass traits. J. Agric. Sci., Camb, 72, 289-295.

Geay Y., Malterre C., 1973. Croissance, rendement et composition des carcasses de jeunes bovins de différentes races. Bull. Techn. du CRZV Theix No. 14, 17-20.

GEAY Y, 1975. Fitting the diet to the potential of the animal. In : Improving the Nutritional Efficiency of Beef Production. Com. Eur. Com. 5488 ${ }^{\mathrm{e}}$, Theix, 14-17 October 1975. Ed. by J.C. TAYLER and J.M. Wilkinson, UK, p. 333-347.

Geay Y., Robelin J., Beranger C., 1976a. Influence du niveau alimentaire sur le gain de poids vif et la composition de la carcasse de taurillons de différentes races. Ann. Zootech. 25, 287-298.

GEAY Y., ROBELIN J., JARRIGE R., 1976b. The influence of the metabolisable energy content of the diet on the efficiency of energy utilisation for young fattening bulls, Proc. 7th Energy symposium - EAAP Publ. No. 19. Ed. M. Vermorel and G-De Bussac, ClermontFerrand, 1976, p. 225-228.

Geay Y., Robelin J,, 1979. Variation of meat production capacity in cattle due to genotype and level of feeding : genotype - nutrition interaction. Livest. Prod. Sci. 6, 263-276.

Guenther J.J., Buschmann D.H., Pope L.S., Morrison R.D., 1965. Growth and development of the major carcase tissues in beef calves from weaning to slaughter weight, with reference to the effect of plane of nutrition. J. Anim. Sci. 24, 1184-1191.

Henrickson R.L., Pope L.S., Hendrickson R.F., 1965. Effect of rate of gain of fattening beef calves on carcass composition. J. Anim. Sci. 24, 507-513.

KaY M., MacDearmid A., Massie R., 1970. Intensive beef production. 11. Replacement of cereals with ground straw. Anim. Prod. 12, 419-424.

Kay M., Massie R., MacDearmid A., 1971. Intensive beef production. 12. Replacement of concentrates with chopped dried grass. Anim. Prod. 13, 101-106.

Lanari D., Susmel P., 1979. Feed-lot beef production from maize silage. Euromais, European Maize Congress, Cambridge, 3 - 7 September.

Levy D., Holzer Z., Volcani R., 1968. The effect of age and liveweight on feed conversion and yield of saleable meat of' intact Israeli-Friesian male calves. Anim. Prod. 10, 325-330.

Levy D., Holzer Z., Volcani R., 1970. Concrete slatted floors vs bedding for fattening Israeli-Friesian bull calves. J. Anim. Sci. 31, 815-820.

Levy D., Holzer Z., Neumark H., Amir S., 1974. The effects of dietary energy content and level of feeding on the growth of Israeli-Friesian intact male cattle. Anim. Prod. 18, $67-73$

Levy D., Holzer Z., Folman Y., 1975. Effect of concentrate roughage ratio on the production of beef from Israeli-Friesian bulls slaughtered at different liveweights. Anim. Prod. 20, 199-205.

LeVy D., Holzer, Z., Folman Y., 1976. Effect of plane of nutrition, diethylstilboesterol implantation and slaughter weight on the performance of Israeli-Friesian intact malecattle. Anim. Prod. 22, 55-59.

Meyer J.H., Hull J.L., WeitKamp W.H., Bonilla S., 1965. Compensatory growth responses of fattening steers following various low energy intake regimes on hay or irrigated pasture. J. Anim. Sci. 24, 29-37.

Montgommery M.J., BaumgardT B.R., 1965. Regulation of food intake in ruminants. 1. Pelleted rations varying in energy concentration. J. Dairy Sci. 48, 569-579.

Pickard D.W., Swan H., Lamming G.E., 1969. Studies on the nutrition of ruminants. 4. The use of ground straw of different sizes for cattle from twelve weeks of age. Anim. Prod. 11, 543-550.

Pirie R., Greenhalgh J.F.D., 1978. Alkali treatment of straw for ruminants. I. Utilization of complete diets containing straw by beef cattle. Anim. Feed Sci. Technol. 3, 143-154. 
Prior R.L., Kohlmeier R.H., Cundiff L.V., Dikeman M.E., Crouse J.D., $1977 . \quad$ Influence of dietary energy and protein on growth and carcass composition in different biological types of cattle. J. Anim. Sci., 45, 132-146.

Richardson D., SMITH E.F., BAKer F.H., Cox R.F., 1961. Effects of roughage-concentrate ratio in cattle fattening rations on gains, feed efficiency, digestion and carcass. J. Anim. Sci. 20, 316-318.

Rohr K., Daenicke R., 1978. Untersuchungen über den Einfluss des Fütterrungsniveaus und der Energieconcentration der Ration auf Pansenfermentation, Gewichtszuwachs und Slachtkörperzusammensetzung schwarzbunter Mastbullen. Zïchtungskunde, 50, 67-77.

Swan H., Lamming G.E., 1970. Studies on the nutrition of ruminants. 5. The effect of diets containing up to 70 per cent ground barley straw on the liveweight gain and carcass composition of yearling Friesian cattle. Anim. Prod. 12, 63-70.

VAN Es A.J.H., 1976. Meat production from ruminants. Proc. Symp. on Growth and Productivity of Meat Animals. Eds. D. Lister, D.N. Rhodes, V.R. Fowler, H.F. Fuller, Plenum Press, Prestbury, p. 391-401.

Waldman R.C., Tyler W.J., Brungardt V.H., 1971. Changes in carcass composition of Holstein steers associated with ration energy level and growth. J. Anim. Sci. 32, 611-619.

Weiss R.L., BaumgardT B.R., Barr G.R., BrungardT V.H., 1967. Some influences on rumen volatile fatty acids upon carcass composition and performance in growing and fattening steers. J. Anim. Sci. 26, 389-393.

Witt M., Andreae U., Kallweit E., 1971. Einfluss unterschiedlicher Fütterungsintensität auf Wachstum und Fettansatz beim Rind, untersucht an eineiigen Zwillingsbullen. Züchtungskunde 43, 173-186. 